\title{
Innovative Regional Development through Triple Helix Collaboration: A Comparative Case Study of Strategic Structures and Implementation
}

\author{
Tuomo Kinnunen*, Satu Rinkinen**, Jukka \\ Majava $^{* * *}$ and Jay Gillette ${ }^{* * *}$
}

*VTT Technical Research Centre of Finland LTD

P.O. Box 1000

FI-02044 VTT, Finland

**Lappeenranta University of Technology

LUT Lahti

Saimaankatu 11

FI-15140, Finland

***Industrial Engineering and Management

University of Oulu

P.O. Box 4610

FI-90014, Finland

**** Ball State University

Muncie, Indiana 47306

USA

E-mail: tuomo.k.kinnunen@vtt.fi

E-mail: satu.rinkinen@lut.fi

E-mail: jukka.majava@ oulu.fi

E-mail: jaygillette@bsu.edu

*Corresponding author

\begin{abstract}
Intense global competition forces regions to seek new ways to boost innovativeness and the success of local enterprises. This paper focuses on triple helix collaboration to support regional innovation-led development and economy. Various options exist for structuring and implementing triple helix collaboration. However, current empirical knowledge is inadequate for stakeholders interested and involved in regional strategy creation and implementation. This study analyses the strategic structures and implementation of triple helix collaboration in two regional cases: Brainport (Netherlands) and Oulu Innovation Alliance (OIA, Finland). Case Brainport introduces a holistic approach and high profile role in regional development, whereas case OIA demonstrates the knowledge institutes' role in regional development in five spearhead areas. The cases illustrate two empirical ways to utilise triple helix mandate and strategic structures in regional development and strategy processes. The case comparison demonstrates diverse options for organising triple helix collaboration.
\end{abstract}

Keywords: regional development; regional innovation; triple helix; collaboration; innovation; empirical case studies. 
Author

Biographical notes: Tuomo Kinnunen (Dr Sc) is a research scientist and a project manager in VTT Technical Research Centre of Finland. He has experience from several international research and development projects. He worked as a project manager in Business ecosystems and platforms for innovations (BECSI) project 2014-2016 at the University of Oulu and as a guest researcher at Eindhoven University of Technology 2014 - 2015. Currently his research interests include business ecosystem and smart mobility.

Satu Rinkinen (Dr Sc) is a post-doctoral researcher in LUT Lahti at Lappeenranta University of Technology and she has worked in several research and development projects. Her research interests include innovation systems, innovation policy and regional development.

Jukka Majava (Dr Sc) is a university lecturer and adjunct professor in Industrial Engineering and Management at the University of Oulu, Finland. His industrial experience includes technology and ecosystem marketing, partner and project management, and business and supply chain development at Nokia Corporation. He has research interests in product innovation, business networks and supply chain development.

Jay Gillette $(\mathrm{PhD})$ is a professor in the Center for Information and Communication Sciences at Ball State University, USA. He served as Fulbright-Nokia Distinguished Chair in Information and Communications Technology at the University of Oulu, Finland 2014-2015. He has operational and research experience in the American telecommunications industry and has served as a fellow at three technology policy institutes. His research interests focus on information and communications technology for economic and community development (ICT for ECD).

This paper is a revised and expanded version of a paper entitled 'Strategic Structure and Implementation of Regional Triple Helix Collaboration: Comparative Case Study' presented at 11th European Conference on Innovation and Entrepreneurship: ECIE 2016, Jyväskylä, Finland, 15-16 September 2016.

\section{Introduction}

This study focuses on triple helix collaboration to support regional innovation-led development and economy - especially on questions concerning the strategic structures of regional collaboration in the triple helix of government, industry and knowledge institutions. Regional innovation activity is often studied through the regional innovation systems lens. Such systems consist of several innovation networks which again consist of heterogeneous groups of actors such as firms, technology centres, higher education organisations and development organisations (Tura and Harmaakorpi, 2005).

As global economic competition is becoming more intense, regions seek new ways to boost regional innovativeness and economic success of local enterprises. Strategic triple helix collaboration is seen as one of these ways. 'Strategic' means long-term arrangements, decided as a result of strategy-development processes, between main triple helix organisations.

However, triple helix collaboration can be implemented in various ways. Regions have diverse, challenging options to structure and implement triple helix collaboration (Asheim and Coenen, 2006). Thus, gaining more knowledge about the role and possible effects of different 
Title

strategic triple helix structures on regional collaboration and development is important for actors and parties involved in regional strategy and implementation.

In practice, the implementation of truly beneficial triple helix collaboration is a challenging task, where intermediary organisations are needed to support, facilitate and govern collaboration. However, despite the extensive triple helix literature (e.g., Etzkowitz and Leydesdorff, 1995; Etzkowitz and Leydesdorff, 2000) implementation of triple helix collaboration is an acknowledged challenge (Asheim and Coenen, 2006) that lacks empirical knowledge.

This study aims to clarify the role of strategic structures in regional triple helix collaboration. A strategic structure is understood as a distinct contractual and organisational setting where main regional triple helix parties are committed for the long-term to organise triple helix collaboration. The goal is to understand how triple helix actors in highly innovative regions can structure and implement triple helix collaboration to support innovation-led economy. Our research question is condensed into the following:

What role can strategic structures and implementation of triple helix collaboration play in regional development?

The research question is answered by analysing two empirical case examples in highly innovative regions: Brainport (Netherlands) and Oulu Innovation Alliance (OIA, Finland). These two regional cases were selected for analysis and comparison based on the following criteria: the regions are located outside metropolitan areas around medium-sized cities, and characterised at the highest level of innovation spirit in Europe (Giffinger et al., 2014); the researchers were able to gain in-depth understanding about the cases (Yin, 2003); together with predominant strategic structures featuring long-term commitment by key triple helix parties in the regions. The research data was collected from multiple sources and included documents, meetings, and observation.

For the background of the empirical study, we review literature on triple helix collaboration and innovation-led regional development. Then our research design and data are explained. Case descriptions and analyses follow. Finally, we present conclusions of the study.

\section{Literature review}

\subsection{Regional innovation system and collaboration networks}

In knowledge-based economies, national and regional development activities are mostly innovation-led. These activities aim at enhancing competitiveness, creating new businesses and jobs and overall well-being in the society, through development of innovation environments and systems. Viewing innovations as a result of a complex social processes requiring collaboration between different actors and organisations during the process has also led innovation policies to focus on supporting networking and collaboration between for example regional innovation actors.

In supporting regional innovation activities and enhancing regional innovativeness, innovation systems theory has been widely applied. This systems approach originates from discussion on national systems of innovation (Edquist, 1997; Freeman, 1987; Lundvall, 1992; Nelson, 1993). From these, the regional dimension of innovation systems theory was presented by Philip Cooke and further developed by several other authors (e.g., see Cooke, 1992, 1998, 2001, 2008; Asheim and Isaksen, 1997, 2002; Autio, 1998). 


\section{Author}

The Regional Innovation System (RIS) concept became popular among practitioners developing and realising innovation policies at the regional level. Policy tools and actions based on the innovation system approach focus not only on traditional input-output relationships, but also on social and institutional factors that affect economic development of the region (Kautonen, 2006). The RIS approach has been a useful tool for regional innovation policies, especially as a catalyst to promote innovativeness among small and medium-sized enterprises (SMEs), by connecting the SMEs with the regional innovation support infrastructure (Asheim and Coenen, 2006).

Autio (1998) presents RIS consisting of two subsystems: (1) the knowledge generation and diffusion subsystem that covers various institutions responsible for the production and diffusion of knowledge and skills; and (2) the knowledge application and exploitation subsystem that consists of companies and their clients, suppliers, competitors and industrial partners. Innovation systems also include intermediary organisations that work in the intersections of knowledge producers and knowledge exploiters and operate as a part of RIS's innovation support infrastructure (Smedlund, 2006). For regional innovation and economic spatial diffusion of knowledge and connecting also to global innovation networks requires interaction between different regional as well as cross-regional interaction (Anttiroiko et al. 2016; Henning \& Saggau, 2012).

As an innovation policy approach, RIS seeks to enhance stronger networking, collaboration and association between innovating partners (as RIS is considered a social system). When innovations are not seen merely as the result of linear processes starting from scientific research and leading to practical applications, the need for new collaboration models for universities, firms and public policy actors is emphasised from the policy perspective. In these regional systems innovations are seen as the result of social interaction of industry, government and university or other higher education organisations and research institutes (Cooke, 1998; Doloreux and Parto, 2005, Asheim and Coenen, 2006). Therefore, one key aim of RIS-based regional innovation policies has been supporting this triple helix interaction between firms, universities and the public sector in different ways.

\subsection{Triple helix collaboration}

As presented above, the triple helix model has become a widely-utilised model in regional context, although in the early triple helix model publications (Etzkowitz and Leydesdorff, 1995; Etzkowitz and Leydesdorff, 2000) the model is discussed in national context. The concept has been applied to regional contexts, describing regional collaboration between universities, firms and government. The principles of the triple helix model have been adopted widely and triple helix collaboration is nowadays seen as vital for the success of regional innovation and development in knowledge-based economies.

The triple helix concept initiated by Etzkowitz and Leydesdorff in the 1990s represents the shift from industry-government combinations dominating Industrial Society, to the Knowledge Society where the potential for innovation lies more in university or research institutions and a triadic relationship between university, industry and government. Hybridization of elements from university, industry and government was seen to generate new formats for the creation, transfer and application of new knowledge (Ranga \& Etzkowitz, 2013).

The triple helix model was connected to the changing role of university in economic development, and stressing the importance of new knowledge for economic development. The role of university was seen important not only in teaching and research but increasingly also in 
Title

its "third mission" of directly contributing to industry and economic development. (Etzkowitz and Leydesdorff, 1995; Etzkowitz and Leydesdorff, 2000.)

Policy-wise the objective of following the triple helix model is to create an innovative environment consisting of university spin-off firms, tri-lateral initiatives for knowledge-based economic development, and strategic alliances among firms, government laboratories and academic research groups (Etzkowitz and Leydesdorff, 2000). These initiatives can be encouraged by government through for example direct or indirect financial assistance. Strategic triple helix alliances cut across traditional sectoral borderlines, and cooperation between industry and government no longer need to follow the traditional arrangements between national governments and specific industrial sectors (Etzkowitz and Leydesdorff, 2000).

In Europe, the latest development and policy discussions have emphasised the need to renew traditional triple helix models to include the public as a fourth helix. Carayannis and Campbell (2009) identify this fourth helix consisting of a 'media-based and culture-based public', which associates with 'media, creative industries, culture, values, life styles, art and perhaps also the notion of the creative class' (Carayannis and Campbell, 2009, p. 206). This fourth helix is seen as a key part of promoting knowledge-based economy, since the public influence every national innovation system. Also, ideas about adding yet a fifth helix to the model have been presented (see e.g. Carayannis et al., 2012).

However, the quadruple helix has received more attention in policy discussions and it has been taken as a part of the Smart Specialisation policy approach, a regional policy framework for innovation-driven growth. Markkula (2014) argues that in the context of Smart Specialisation and its extensive implementation in Europe, the triple helix concept needs to be taken into active use but in a more modern form (see also Foray et al., 2012). The advantage of the newer quadruple helix concept is that it allows for a variety of innovations other than strongly science- or technology-based ones, in the spirit of the wider concept of innovation, for example the Smart Specialisation strategies. Many studies have brought out the idea of and need for a quadruple helix (e.g., see also MacGregor et al., 2010; Curley and Salmelin, 2013; Lindberg et al., 2014).

The triple helix model in its original form is a model for analysing university-industrygovernment relations. In policy contexts, triple helix principles are often used rather loosely to underpin the importance of the relationships and collaboration among these three spheres. For example, when studying the development policy efforts in a small Portuguese municipality, Rodrigues and Melo (2012) noticed that the influence of scientific triple helix model to policy and planning was symbolic rather than objective. Rodrigues and Melo (2012) argue that the appealing idea of the interactive dynamics bringing together university, government and industry, supplemented by simple graphics presenting the institutional collaboration, has transformed the original triple helix model merely into an easy-to-use symbolic metaphor. Pugh (2017) also notes that implementing the triple helix model in practice considering the regional context where the model is utilised, for example when utilising it in weaker regions, and increasing the focus on diverse regional setting and spaces.

Rosenlund et al. (2015) have differentiated the analytical model of triple helix from the management model of triple helix and they emphasise the "people side" of triple helix management, including the role of trust and social capital. In networked relationships based on for example trust and social capital, intermediary organisations can work as facilitating and coordinating actors/organisations. Smedlund (2006) has listed the roles of different intermediaries in the dynamics of a regional knowledge system and emphasises promoting triple helix cooperation as the main role of regional/meso level intermediaries in innovation networks. Todeva (2013) examines the governance of innovation and intermediation in triple helix interactions through case studies in Britain and states that empirical observations confirm the 
need for intermediaries to engage in triple helix network creation, and the management of networked relationships.

The benefits of engaging an intermediary organisation in such collaboration (as with providing unique governance structure for the management of collaborative $R \& D$ projects, facilitating development of a regional innovation strategy) was also noted in Johnson's (2008) research on the Canadian intermediary organisation Precarn Incorporated. Johnson's analysis shows that from the resource-based view, intermediaries exist to provide specific resources and to play specific roles that individual triple helix members cannot or are unwilling to play. Future research is suggested to focus on testing which specific resources lead to success for these intermediary organisations in helping facilitate triple helix collaboration.

In order to manage the triple helix connectivity within smart specialisation strategy implementation, Virkkala et al (2017) have created a connectivity model and utilised it as a part of Ostrobothnia region's smart specialisation and entrepreneurial discovery process. By analysing the gaps in triple helix interactions and utilising focus group meetings and policy interventions the model can help improve regional cooperation by pointing out bottlenecks and focusing support on the biggest issues hindering cooperation. Triple helix collaboration requires ability to cross boundaries between different sectors. Rosenlund et al. (2017) present how difficulties in micro-level triple helix collaboration can be the result of difficulties related to crossing different boundaries. In their case these difficulties emerged due to different expectations of knowledge and the different sector-specific ways of working. They suggest that developing boundary management, boundary spanners and common arenas for dialogue could help overcoming these triple helix boundaries in micro-level collaboration.

Leydesdorff and Zawdie (2010) consider the triple helix perspective of innovation systems theory discussed in previous section. They state that triple helix provides a model of the structure and dynamics underlying the innovation system functioning at various levels. In contrast to the (national) innovation systems theory which presents the firms as having the lead role in innovation, the triple helix model emphasises the role of university in innovation (Etzkowitz and Leydesdorff, 2000). Ranga and Etzkowitz (2013) have created a triple helix systems approach, which combines the traditional triple helix model with innovation systems theory. Following the elements of innovation systems, Ranga and Etzkowitz (2013) define a triple helix system as a set of components, relationships between the components and functions of the system.

Asheim and Coenen (2006) argue that even though the dynamic triple helix perspective has increased among policy makers and researchers there are challenges in its implementation. They state that this approach 'does not give much guidance on how a triple-helix based collaboration could be functional, operational and implemented in concrete policy settings in order to contribute to constructing regional advantage' (p. 91). The challenges of triple helix collaboration and its implementation stem for example from different logics and expectations and from the varying degree of commitment of different regional actors over time (Sandström and Ylinenpää, 2012). Previous research calls for research on triple helix implementation and both theoretical and practical advice on how to organise regional strategic collaboration between industry, government and university. The triple helix perspective enables us to study innovation systems in empirical terms (the extent to which arrangements can be considered to constitute a system) and analyse best-practice trends (such as, whether better knowledge-based arrangements are possible). 
Title

\section{Research design}

Our qualitative case study compares triple helix collaboration in two regional contexts (Yin, 2003). These cases represent regions around two medium-sized smart cities in Europe that have significantly high-level innovation spirit (Giffinger et al., 2014). As Appendix 1 indicates, these two regions are very innovation-intensive based on international patent (PCT) applications per inhabitant. The number of PCT patent applications per inhabitant in these regions can even be compared with Silicon Valley. In addition, triple helix collaboration and regionally predominant strategic structures appear clearly in both regions because of dominant triple helix components a dominant city, a dominant university and a dominant university of applied sciences.

Triangulation is considered important in case study research because it enhances reliability and validity (Eisenhardt, 1989; Voss et al., 2002). Triangulation requires data collection from multiple sources: the research data include several sources listed in Table 1. The primary data source consists of documents including official, publicly available publications, reports, research papers, presentation slides and internet sites. In addition, observation and meetings with key triple helix representatives from both regions were used to complement and verify the results. The data analysis followed Eisenhardt (1989). The analysis was conducted using a qualitative approach. The researchers analysed the materials and notes to find connections, patterns, and comparisons. The key findings are presented in section 4. The comparative case analysis focuses on past, established triple helix structures and operations from 2005 to 2015.

Table 1. Case data sources.

\begin{tabular}{|c|c|c|}
\hline & Brainport Eindhoven & Oulu Innovation Alliance (OIA) \\
\hline Documents & $\begin{array}{l}\text { Brainport Eindhoven (2005) Brainport } \\
\text { navigator 2013: Beyond Lissabon! - } \\
\text { Summary; Brainport Development } \\
\text { (2011) Summary Brainport 2020: top } \\
\text { Economy, Smart Society; Brainport } \\
\text { Development (2013) Brainport monitor - } \\
\text { annual publication; Brainport } \\
\text { Development (2012) Brainport monitor } \\
2012 \text { - summary }\end{array}$ & $\begin{array}{l}\text { Oulu Triple Helix - Final report on } \\
\text { advancing university activities as a part of } \\
\text { innovation environment (the basis for } \\
\text { establishing OIA), December } 2007 \text {; OIA - } \\
\text { Alliance agreement } 2.3 .2009 \text {; OIA } \\
\text { presentation slides } 20.12 .2013 \text {; OIA and } \\
\text { innovation centres' evaluation report } \\
\text { (2015) - internal document }\end{array}$ \\
\hline Presentations & $\begin{array}{l}\text { The power of cooperation, 30th of } \\
\text { October } 2014 \text { Eindhoven, Pieter } \\
\text { Noordzij, Brainport Development; The } \\
\text { Brainport model and the innovation } \\
\text { strategy of our region, 6th May } 2015 \\
\text { Oulu, Joep Brouwers, Vice Director, } \\
\text { Brainport Development. }\end{array}$ & $\begin{array}{l}30 \text { years of cooperation, } 5 \text { th May } 2015 \\
\text { Oulu, panel discussion of six leaders of } \\
\text { OIA alliance partners. }\end{array}$ \\
\hline Internet sites & $\begin{array}{l}\text { http://www.brainport.nl, } \\
\text { http://www.brainportdevelopment.nl/ }\end{array}$ & $\begin{array}{l}\text { http://www.ouluinnovationalliance.fi, } \\
\text { http://cht.oulu.fi/, http://www.cie.fi/, } \\
\text { http://www.cee.fi/, } \\
\text { http://www.printocent.net/, } \\
\text { http://www.maigbe.fi/ }\end{array}$ \\
\hline
\end{tabular}


Author

Literature Fernández-Maldonado \& Romein (2010), Rantakokko (2012), Rantakokko (2014)

Horlings, L. G. (2014), Schaap \&

Ostaaijen (2015)

\section{Results}

The study provides case descriptions and comparative analysis of strategic triple helix structures in two highly innovative regions. The results illustrate retrospectively the case regions' empirical setting for structuring, governing and facilitating triple helix collaboration to support innovation-led regional development. The main characteristics of the cases are described in Table 2.

Table 2. Case descriptions.

\begin{tabular}{|c|c|c|}
\hline $\begin{array}{l}\text { Name and } \\
\text { slogan }\end{array}$ & $\begin{array}{l}\text { Brainport Eindhoven (Case Brainport) } \\
\text { "Co-creating future" }\end{array}$ & $\begin{array}{l}\text { Oulu Innovation Alliance (Case OIA) } \\
\text { "Ideas into Business" }\end{array}$ \\
\hline $\begin{array}{l}\text { Contractual } \\
\text { basis }\end{array}$ & $\begin{array}{l}\text { Brainport Foundation } \\
\text { Founded } 2005\end{array}$ & $\begin{array}{l}\text { Strategic agreement } \\
\text { Signed } 2009\end{array}$ \\
\hline $\begin{array}{l}\text { Strategic } \\
\text { objective }\end{array}$ & $\begin{array}{l}\text { To create a common vision and strategy and } \\
\text { a strong focused regional development } \\
\text { project portfolio (strategy and } \\
\text { implementation) }\end{array}$ & $\begin{array}{l}\text { To strengthen strategic cooperation } \\
\text { between the parties, advance co-planning } \\
\text { of initiatives and develop partnership } \\
\text { between OIA network, state government } \\
\text { and regional administration }\end{array}$ \\
\hline $\begin{array}{l}\text { Triple } \\
\text { Helix } \\
\text { partners }\end{array}$ & $\begin{array}{l}\text { The Supervisory Board of Brainport } \\
\text { foundation: } \\
\text { - representatives of five governmental } \\
\text { organisations (including four city mayors) } \\
\text { - leaders of six knowledge institutes } \\
\text { - representatives of five industrial } \\
\text { organisations }\end{array}$ & $\begin{array}{l}\text { OIA partners: } \\
1 \text { governmental organisation } \\
3 \text { knowledge institutes } \\
1 \text { industrial company }\end{array}$ \\
\hline $\begin{array}{l}\text { Primary } \\
\text { actors }\end{array}$ & $\begin{array}{l}\text { Brainport Development company } \\
\text { Owned } 50 \% \text { by the strategic foundation and } \\
50 \% \text { by the municipalities of the region }\end{array}$ & $\begin{array}{l}\text { Five OIA Innovation Centres } \\
\text { Closely connected to the main knowledge } \\
\text { institutes of the region }\end{array}$ \\
\hline $\begin{array}{l}\text { The scope } \\
\text { of activities }\end{array}$ & $\begin{array}{l}\text { Broad scope of activities that are categorised } \\
\text { into the domains of People, Technology, } \\
\text { Business and Basics and focused on regional } \\
\text { innovation-led development: } \\
\text { - Encourages and develops regional and } \\
\text { (inter)national projects and programmes } \\
\text { which, by preference, are carried out under } \\
\text { the responsibility of the 'problem owners' } \\
\text { - Builds Brainport brand and promotes } \\
\text { Brainport nationally and internationally }\end{array}$ & $\begin{array}{l}\text { Narrow scope of activities focusing around } \\
\text { rather independently operating innovation } \\
\text { centres and their focus areas to generate } \\
\text { business from research, development and } \\
\text { innovation (RDI) projects and ventures }\end{array}$ \\
\hline
\end{tabular}


Title

\begin{tabular}{|c|c|c|}
\hline \multirow{3}{*}{$\begin{array}{l}\text { Target } \\
\text { areas of } \\
\text { activities }\end{array}$} & \multicolumn{2}{|l|}{$\begin{array}{l}\text { - Monitors set of macro-economic indicators } \\
\text { and analyses concerning the regional } \\
\text { ecosystem }\end{array}$} \\
\hline & $\begin{array}{l}\text { - Facilitates regional industry through } \\
\text { business advice and funding, incubation } \\
\text { facilities, business premises and business } \\
\text { centres }\end{array}$ & \\
\hline & $\begin{array}{l}\text { The five top sectors of Brainport Eindhoven: } \\
\text { - High Tech Systems \& Materials } \\
\text { - Food \& Technology } \\
\text { - Automotive } \\
\text { - Lifetec \& Health } \\
\text { - Design }\end{array}$ & $\begin{array}{l}\text { The spearhead areas of OIA innovation } \\
\text { centres: } \\
\text { - Cleantech } \\
\text { - Health and wellbeing technology } \\
\text { - 3D internet } \\
\text { - Printed intelligence } \\
\text { - Research and education of global business } \\
\text { and economics }\end{array}$ \\
\hline
\end{tabular}

\subsection{Case Oulu Innovation Alliance (Case OIA), Finland}

Case OIA presents a focused approach to strategic triple helix collaboration. The strategic structure of OIA is based on the strategic agreement signed 2009 between partners: one governmental (City of Oulu), three knowledge institutional (University of Oulu, Oulu University of Applied Sciences, and VTT Technical Research Centre of Finland), and one industrial partner (Technopolis). The agreement resulted from a specific triple helix strategy preparation, conducted mainly in 2007. Case OIA was built on decades' history of regional triple helix collaboration. Strategic triple helix collaboration was active in initiation phase of OIA (20082012) and its innovation centres. Since the OIA operations were established, the strategic alliance structure has served more as a discussion forum. Triple helix collaboration has been driven rather independently by each innovation centre - with shared ownership and triple helix mandate - that are closely connected with the operations of knowledge institutes. The centres are scoped to support, compose and coordinate research, development and innovation activities in the selected spearhead areas. Figure 1 illustrates the innovation centres and partners of Oulu Innovation Alliance. 
Figure 1. The innovation centres and partners of Oulu Innovation Alliance.

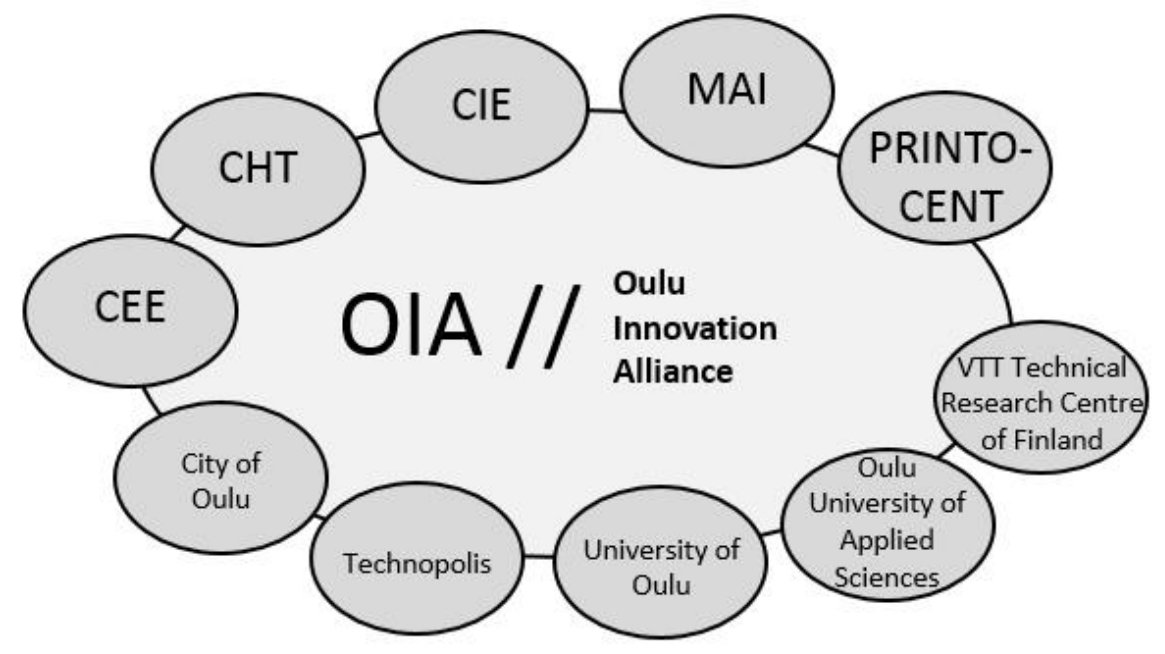

Source: OIA (2017)

The five innovation centres of OIA have dedicated roles. Centre for Environment and Energy (CEE) focuses on turning innovations in the environmental, energy and cleantech sectors into business. Centre for Health and Technology (CHT) is responsible for health and wellbeing technologies, especially connected health. Center for Internet Excellence (CIE) conducts research of internet technologies, especially 3D internet. Martti Ahtisaari Institute of Global Business and Economics (MAI) deals with research and education of global business and economics. PrintoCent is responsible for industrialisation and commercialisation of printed intelligence.

The implementation of triple helix collaboration of Case OIA is focused around those five innovation centres, especially advancing and strengthening the role of universities in regional innovation-led economy. The role of implementation of triple helix collaboration in regional development is thus dependent on the innovation centres' capabilities to generate business from research, development, and innovation (RDI) projects and ventures. Overall, the success of OIA as a strategic triple helix structure depends on selecting right focus areas, with good fit to regional strengths and competences, and success of the innovation centres in the long term.

\subsection{Case Brainport Eindhoven, The Netherlands}

Brainport Eindhoven has adopted a holistic approach to strategic triple helix collaboration. The strategic structure of Brainport Eindhoven is based on the foundation established 2005 and supervised by five governmental, six knowledge institutional and five industrial representatives. This structure and the strategic frame was formed in past regional development programs that successfully addressed the severe regional economy crisis in the preceding decade. Case Brainport is running an iterative triple helix strategy process to create and update the shared vision and strategy, and to facilitate a strong, focused regional development project portfolio. The central actor in triple helix collaboration of Case Brainport is the development company, 
Title

Brainport Development. That company organises implementation of the shared agenda that is set by the supervisory board of the foundation. The shared agenda includes the range of diverse activities strengthening and connecting five existing and emerging knowledge-intensive clusters in regional innovation-led economy, as illustrated in Table 3.

Table 3. Examples of Brainport programs and activities.

\begin{tabular}{llll}
\hline People & Technology & Business & Basics \\
\hline $\begin{array}{l}\text { Brainport talentBox - } \\
\text { online career platform }\end{array}$ & $\begin{array}{l}\text { High Tech Campus } \\
\begin{array}{l}\text { Eindhoven - High tech } \\
\text { business park and } \\
\text { industrial R\&D center }\end{array}\end{array}$ & $\begin{array}{l}\text { Brainport Industries - } \\
\text { An association of High } \\
\text { Tech suppliers }\end{array}$ & $\begin{array}{l}\text { Holland Expat Center } \\
\text { South - Services for } \\
\text { expats and their families } \\
\text { to settle in }\end{array}$ \\
$\begin{array}{l}\text { International School } \\
\begin{array}{l}\text { Dutch Technology centre } \\
\text { Week (DTW) - Mass } \\
\text { event }\end{array}\end{array}$ & $\begin{array}{l}\text { Automotive Campus - } \\
\text { Automotive business } \\
\text { park and R\&D center }\end{array}$ & $\begin{array}{l}\text { Brainport Networking } \\
\text { Financials - A network } \\
\text { of financiers }\end{array}$ & $\begin{array}{l}\text { Cross-border issues, e.g. } \\
\text { traffic connections }\end{array}$ \\
\hline
\end{tabular}

The development company monitors annually a number of macro-economic indicators, studies and analyses about the region. Table 4 presents the quantitative indicators used to monitor annual regional development and effectiveness of shared agenda implementation.

Table 4. Quantitative indicators of monitoring the regional development (Brainport monitor 2013).

\begin{tabular}{llll}
\hline People & Technology & Business & Basics \\
& & & \\
\hline 1 Population & 9 Total R\&D expenses & 18 Gross Regional & 28 Mobility \\
2 Migration & 10 Public R\&D & Product & 29 Shuttle \\
3 Foreign nationals & spending & 19 Economic Growth & 30 Traffic intensity \\
4 Working population & 11 Private R\&D & 20 Gross value added & 31 Flight connections \\
5 Gross labor (of aged & spending & and labor productivity & 32 Quality of life \\
15-65) & 12 Top 30 company & 21 Export; industry & 33 Entertainment \\
6 Unemployment & R\&D spending & exports and export & 34 Culinary \\
7 Higher education & 13 Publications & sectors & 35 Proximity to \\
8 Lifelong learning & 14 Citations & 22 Net number of start- & amenities \\
& 15 Patents & ups & \\
& 16 Cooperation in & 23 Fast growing & \\
& innovation & companies & \\
& 17 Turnover from & 24 Vacancies & \\
& innovation & 25 Number of jobs & \\
& & 26 High tech: branches, & \\
& & net new companies and & \\
& & number of jobs & \\
& & 27 Spearhead sectors & \\
& &
\end{tabular}


In this case, the triple helix structure and collaboration itself is branded as 'Brainport', and together with strong, fact-based narrative, is utilised for lobbying and advancing regionrecognition, nationally and internationally.

\subsection{Comparative Case Analysis}

Our study analysed the roles of strategic structures and implementation of triple helix collaboration in regional development. As Asheim and Coenen (2006) have argued policy makers and researchers are aware of triple helix concept, but empirical guidance on the implementation of triple-helix based regional collaboration is currently insufficient. Our study analyses two different approaches. Case Brainport Eindhoven shows that strategic triple helix structure and implementation may take a holistic and high-profile role in representing the region and supporting regional innovation-led development (see e.g. Table 4, Brainport monitor, 2013). The strategic structure of Case Brainport is a foundation supervised by sixteen main triple helix parties. Case Brainport emphasises the triple helix governance model with shared ownership and shared strategy. In Case Brainport, a triple helix development company has replaced several separate city development agencies. This company - with shared ownership and triple helix mandate has taken a broad and active role in organising implementation of shared agenda, but is not necessarily responsible for implementing the activities.

In comparison with the Eindhoven case, the role of OIA in Case OIA Oulu is narrow, and directly connects knowledge institutes and RDI activities in selected technology focus areas. This type of approach emphasises the role of university in innovation (Etzkowitz and Leydesdorff, 2000). The strategic structure of OIA is an alliance agreement among five main triple helix parties. The implementation of strategic objectives was organised through five innovation centres (see Figure 1, OIA, 2017) and the structure in OIA strengthens the role of knowledge institutes in regional development in the spearhead areas. In comparison, Case Brainport's role is broad and connected to its government-led development company, together with any direct and indirect activities jointly decided as important for regional innovation-led development.

The strategic structures are results of strategy processes reflecting certain temporal and contextual settings. These address particular needs and problems, i.e. severe regional economy crisis in Case Brainport, and globalisation challenges in Case OIA. The strategic structures and implementation of triple helix collaboration take very different roles and development paths in the compared cases. This indicates wide diversity of options for structuring and organising regional triple helix collaboration globally. Context does matter, yet triple helix outcomes grow in significance for innovative regions that can successfully adapt the concept to their specific conditions.

In spite of different approaches taken to implement the triple helix collaboration, the findings from the two cases analysed in our study support the findings by Todeva (2013) by demonstrating the structured management of networked relationships. The results also support the findings by Johnson (2008), who identified governance structures to be important in regional collaboration. In contrast to the arguments by Rodrigues and Melo (2012), our study indicates that the triple helix model can have more value than being merely a symbolic metaphor. 
Title

\section{Conclusions}

Our results contribute to empirical understanding of triple helix collaboration and especially its implementation in the context of regional development. The study contributes to triple helix literature by presenting two empirical cases of strategic triple helix structures and explaining their role in the regions. While societal contexts, visionary leaders, and the legacies of past collaboration have clearly directed the two regions to quite a different strategic structures and implementation of triple helix collaboration, the findings illustrate two evidence-based examples for regional innovation-led development.

The study contributes to the current understanding of the role of strategic structures of triple helix collaboration in general. It particularly illustrates strategic alliance as a key triple helix partnership in advancing and strengthening the role of knowledge institutes (Case OIA). It also demonstrates the effectiveness of a foundation-based strategic structure that innovates the role and governance model of a municipal development company (Case Brainport).

The triple helix model is rather abstract from the governance perspective. Triple helix theory guides application of development theory to practice. However, linking these three spheres in practice means connecting complex functions and finding the best practices considering different contexts. Strategic collaboration structures can enhance the formulation and sustaining of the regional triple helix collaboration. The triple helix model helps examine innovation systems empirically (see also Leydesdorff and Zawdie, 2010; Ranga and Etzkowitz, 2013) and analyse best practices and diverse strategic configurations.

Societal context and need, as well as regional development vision, have a significant effect on strategic triple helix structures. Globally there are numerous forms that triple helix collaboration could take. This study focuses on two types of established structures in highly innovative regions. The results strengthen triple helix literature and understanding of regional innovation-led development. Other types of strategic triple helix structures, compared especially to triple helix collaboration that is implemented without specific strategic structure, can be interesting focus areas for future research.

The case analyses and comparison are especially useful for community leaders, policy makers, managers and other stakeholders involved in strategy processes within and between regional triple helix organisations: government, business and knowledge institutes. The strategic structures and empirical experiences, about organising and utilising triple helix collaboration in highly innovative regions, may be used as a benchmark in other regions and contexts as well.

However, triple helix collaboration can be implemented in diverse ways. Gaining more knowledge about the role and possible effects of different strategic triple helix structures on regional collaboration and development is important for stakeholders involved in regional strategy processes and strategy implementation. Researchers and practitioners may find further insights by applying these findings to different organisational and regional contexts. 


\section{Author}

\section{References}

Anttiroiko, A-V., Laine, M. \& Lönnqvist, H. (2016). Metropolitan strategies for global innovation networking: the case of Helsinki. International Journal of Innovation and Regional Development, Vol. 7, No. 1, pp. 20-35.

Asheim, B. T. \& Isaksen, A. (1997). Location, agglomeration and innovation: towards regional systems in Norway? European Planning Studies, Vol. 5, No. 3, pp. 299-330.

Asheim, B. T. \& Isaksen, A. (2002). Regional innovation systems: The integration of local 'sticky' and global 'ubiquitous' knowledge. Journal of Technology Transfer, Vol. 27, No. 1, pp. 77-86.

Asheim, B. T. \& Coenen L. (2006). Contextualising regional innovation systems in a globalising learning economy: On knowledge bases and institutional frameworks". The Journal of Technology Transfer, Vol. 31, No. 1, pp. 163-173.

Autio, E. (1998). Evaluation of RTD in regional systems of innovation. European Planning Studies, Vol. 6, No. 2, pp. 131-140.

Carayannis, E. G., \& Campbell, D. F. (2009). 'Mode 3'and'Quadruple Helix': toward a 21st century fractal innovation ecosystem. International Journal of Technology Management, Vol. 46, Nos. 3-4, pp. 201234.

Carayannis, E. G., Barth, T. D., \& Campbell, D. F. (2012). The Quintuple Helix innovation model: global warming as a challenge and driver for innovation. Journal of Innovation and Entrepreneurship, Vol 1, No. 1, pp. 2.

Cooke, P. (1992). Regional innovation systems: Competitive regulation in the new Europe. Geoforum, Vol. 23, No. 3, pp. 365-382.

Cooke, P. (1998). Introduction: Origins of the concept. In Braczyk, H-J., Cooke, P. \& Heidenreich, M. (Eds.) Regional innovation systems. Pp. 2-25. London and New York: Routledge.

Cooke, P. (2001). Regional innovation systems, clusters and the knowledge economy. Industrial and Corporate Change, Vol. 10, No. 4, pp. 945-974.

Cooke, P. (2008). Regional innovation systems, clean technology \& Jacobian clusterplatform policies. Regional Science Policy \& Practice, Vol. 1, No. 1, pp. 23-45.

Curley, M., \& Salmelin, B. (2013). Open Innovation 2.0: A New Paradigm. EU Open Innovation Strategy and Policy Group (OISPG). White Paper. [online] https://ec.europa.eu/digital-singlemarket/node/66731. Downloaded as OISPGOpenInnovation20ANewParadigm-WhitePaper.pdf. Accessed 10 May 2016.

Doloreux, D. and Parto, S. (2005). Regional innovation systems: Current discourse and unresolved issues. Technology in Society, Vol. 27, No. 2, pp. 133-153.

Edquist, C. (1997). Introduction. In Edquist, C. (ed.): Systems of innovation. Technologies, institutions and organisations. Pp. 1-35. London and Washington: Pinter.

Eisenhardt, K. M. (1989). Building theories from case study research. Academy of Management Review, Vol. 14, No. 4, pp. 532-550.

Etzkowitz, H. and Leydesdorff, L. (2000). The dynamics of innovation: From national systems and mode 2 to a triple helix of university-industry-government relations. Research Policy, Vol. 29 No. 2, pp. 10923.

Etzkowitz, H. \& Leydesdorff, L. (1995). The triple helix university-industry-government relations: A laboratory for knowledge-based economic development. EASST Review, Vol. 14, pp. 14-19.

Fernández-Maldonado, A., \& Romein, A. (2010). The role of organisational capacity and knowledge-based development: The reinvention of Eindhoven. International Journal of Knowledge Based Development, Vol 1/2, No. 1, pp. 79-96. 
Title

Foray, D., Gobbard, J., Beldarrain, X.G., Landabaso, M., McCann, P., Morgan, K., Nauwelaers, C. \& Ortega-Argilés, R. (2012). Guide to Research and Innovation Strategies for Smart Specialisation (RIS3), European Commission [online] http://ec.europa.eu/regional_policy/sources/docgener/presenta/smart_specialisation/smart_ris3_2012. pdf.

Freeman, C. (1987). Technology Policy and Economic Performance: Lessons from Japan. London: Pinter.

Giffinger, R., Kramar, H., Haindlmaier, G. \& Strohmayer, F. (2014). Ranking of European medium-sized cities. European Smart Cities 3.0. Website. http://www.smart-cities.eu/index.php?cid=01\&ver=3 Accessed 17 December 2015.

Hennig, C. \& Saggau, V. (2012). Networks, spatial diffusion of knowledge and regional economic growth: an agent-based modelling approach. International Journal of Innovation and Regional Development, Vol. 4, No. 3/4, pp. 204-231.

Horlings, L. (2014). Leadership, Governance and Knowledge in an Enterprising Place: The Case of Brainport Eindhoven in the Netherlands. In Lee Pugalis, Joyce Liddle (eds.) Enterprising Places: Leadership and Governance Networks (Contemporary Issues in Entrepreneurship Research, Volume 3) Emerald Group Publishing Limited, pp.149-175.

Johnson, W. (2008). Roles, resources and benefits of intermediate organisations supporting triple helix collaborative R\&D: The case of Precarn. Technovation, Vo. 28, pp. 495-505.

Kautonen, M. (2006). The regional innovation system bottom-up: A Finnish perspective. Acta Universitatis Tamperensis, 545. Tampere: Tampere University Press.

Leydesdorff, L., \& Zawdie, G. (2010). The triple helix perspective of innovation systems. Technology Analysis \& Strategic Management, Vol. 22, No. 7, pp. 789-804.

Lindberg, M., Lindgren, M., \& Packendorff, J. (2014). Quadruple helix as a way to bridge the gender gap in entrepreneurship: The case of an innovation system project in the Baltic Sea region. Journal of the Knowledge Economy, Vol. 5, No. 1, pp. 94-113.

Lundvall, B.-Å. (1992). Ed. National Systems of Innovation: Towards a Theory of Innovation and Interactive Learning. London: Pinter.

MacGregor, S., Marques-Gou, P., \& Simon-Villar, A. (2010). Gauging readiness for the quadruple helix: A study of 16 European organizations. Journal of the Knowledge Economy, Vol. 1, No. 3, pp. 173-190.

Markkula, M. (2014). Renewing the triple helix in a context of Smart Specialisation. Hélice, Vol. 3, No. 8.

Nelson, R.R. (1993). Ed. National innovation systems: a comparative analysis. Oxford: Oxford University Press.

OECD. Innovation indicators. [online] OECD. http://stats.oecd.org/Index.aspx ?DataSetCode=REG_INNO_TL2 (Accessed 27 October 2014).

Oulu Innovation Alliance (2017) Materials. Available at: http://www.ouluinnovationalliance.fi/who-weare/materials/ Accessed January 24, 2017.

Pugh, R. (2017). Universities and economic development in lagging regions: 'Triple helix'policy in Wales. Regional Studies, Vol. 51, No. 7, pp. 982-993.

Ranga, M. \& Etzkowitz, H. (2013). Triple Helix systems: An analytical framework for innovation policy and practice in the Knowledge Society. Industry \& Higher Education, Vol. 27, No. 3, pp. 237-262.

Rantakokko, M. (2012) Smart City as an innovation engine: Case Oulu. Elektrotehniški Vestnik, Vol. 79, No. 5, pp. 248-254.

Rantakokko, M. (2014) Oulu Innovation Alliance: An Open Innovation Ecosystem. In Martin, C. \& Salmelin, B. (eds.), Open Innovation 2.0 Yearbook 2014, European Commission, pp. 105-110. 


\section{Author}

Rodrigues, C. \& Melo, A. (2012). The triple helix model as inspiration for local development policies: An experience-based perspective. International Journal of Urban and Regional Research, Vol. 37, No. 4, pp. 1675-1687.

Rosenlund, J., Hogland, W., Johansson, A.W. \& Seddon, J. (2014). A cross-national environmental cluster collaboration: Shifting between an analytical and management level of triple helix. Science and public policy, Vol. 42, No. 4, pp. 583-593.

Rosenlund, J., Rosell, E., \& Hogland, W. (2017). Overcoming the triple helix boundaries in an environmental research collaboration. Science and Public Policy, Vol. 44, No. 2, pp. 153-162.

Sandström, A. \& Ylinenpää, H. (2012). Research, industry and public sector cooperation - a dynamic perspective. International Journal of Innovation and Regional Development, Vol. 4, No. 2, pp. 144 159.

Schaap, L. \& van Ostaaijen, J. (2015). Good Multi-level Governance, Brainport Eindhoven. In Schaap, L., Gianoli, A., van den Dool, L. \& Hendriks, F. (eds.), The Quest for Good Urban Governance: Theoretical Reflections and Practical Challenges, Springer Fachmedien Wiesbaden, pp. 147-163.

Smedlund, A. (2006). The roles of intermediaries in a regional knowledge system. Journal of Intellectual Capital, Vol. 7, No. 2, pp. 204-220.

Todeva, E. (2013). Governance of innovation and intermediation in Triple Helix interactions. Industry \& Higher Education, Vol. 27, No. 4, pp. 263-278.

Tura, T. \& Harmaakorpi, V. (2005). Social capital in building regional innovative capability. Regional Studies, Vol. 39, No. 8, pp. 1111-1125.

Virkkala, S., Mäenpää, A. \& Mariussen, Å. (2017). A connectivity model as a potential tool for smart specialization strategies. European Planning Studies, Vol. 25, No. 4, pp. 661-679.

Voss, C., Tsikriktsis, N. \& Frohlich, M. (2002). Case research in operations management. International Journal of Operations \& Production Management, Vol. 22, No. 2, pp. 195-219.

Yin, R. (2003). Case Study Research: Design and Methods. 3rd edition. Sage Publications, Thousand Oaks, California. 
Title

Appendix 1. PCT patent applications in Oulu region, Noord-Brabant, and Silicon Valley (OECD, 2014)

\begin{tabular}{|c|c|c|c|c|c|c|}
\hline Variable & Region & 2006 & 2007 & 2008 & 2009 & 2010 \\
\hline \multirow{3}{*}{$\begin{array}{l}\text { PCT patent } \\
\text { applications per } \\
\text { million } \\
\text { inhabitants } \\
\text { (fractional } \\
\text { count; by } \\
\text { inventor and } \\
\text { priority year) - } \\
\text { level }\end{array}$} & $\begin{array}{l}\text { Northern } \\
\text { Ostrobothnia } \\
\text { (Oulu and } \\
\text { surrounding } \\
\text { region) }\end{array}$ & 404,4 & 401,6 & 363,3 & 418,7 & 412,6 \\
\hline & Noord-Brabant & 811,3 & 750,8 & 769,3 & 636,5 & 524,2 \\
\hline & $\begin{array}{l}\text { San Jose-San } \\
\text { Francisco- } \\
\text { Oakland, CA } \\
\text { (Silicon Valley) }\end{array}$ & 674,6 & 663,4 & 576,6 & 565,5 & 543,4 \\
\hline \multirow[t]{3}{*}{$\begin{array}{l}\text { PCT patent } \\
\text { applications - } \\
\text { count }\end{array}$} & $\begin{array}{l}\text { Northern } \\
\text { Ostrobothnia } \\
\text { (Oulu and } \\
\text { surrounding } \\
\text { region) }\end{array}$ & 153,4 & 152,9 & 139,3 & 161,7 & 161,8 \\
\hline & Noord-Brabant & 1960,0 & 1816,2 & 1865,4 & 1549,6 & 1281,3 \\
\hline & $\begin{array}{l}\text { San Jose-San } \\
\text { Francisco- } \\
\text { Oakland, CA } \\
\text { (Silicon Valley) }\end{array}$ & 6352,0 & 6294,1 & 5535,6 & 5492,2 & 5334,6 \\
\hline
\end{tabular}

